- Centro Odontológico Veterinário foram revisadas, constatando-se a ocorrência de 129 focos de fratura mandibular em 91 cães $(2,4 \%)$. Os traumatismos constituíram o principal fator etiológico, representados, principalmente, por brigas com outros animais $(40,2 \%)$ e atropelamentos (13\%); em $25 \%$ dos casos a origem das fraturas nào pôde ser determinada. As fraturas consideradas patológicas corresponderam a $14,1 \%$ do total; em um caso a fratura foi iatrogênica. Pôde-se notar o acometimento significativo de diferentes faixas etárias, mais prevalente em animais com idade em torno de um ano e de 8 anos de idade. Cerca de $70 \%$ dos animais acometidos no estudo foram considerados de pequeno porte, sendo a raça Poodle a mais prevalente, representando $31,8 \%$ do total. Com relação à distribuiçào sexual, as fraturas mandibulares foram diagnosticadas em 63 machos $(68,1 \%)$ e 29 fêmeas $(31,9 \%)$. Em apenas 3,3\% dos casos houve lesão concomitante em maxila. A região molar constituiu o principal foco de fratura mandibular nesta espécie, correspondendo a $46,5 \%$, seguida pela regiào de sínfise e parassínfise mentoniana $(31 \%)$, região pré-molar $(17,8 \%)$, processo angular $(3,9 \%)$ e ramo vertical $(0,8 \%)$. Pôde-se concluir que as fraturas mandibulares apresentam discreta prevalência em càes, acometendo, geralmente animais de pequeno porte. Os principais fatores etiológicos envolvidos nestes casos sào brigas com outros animais e atropelamentos por automóveis, sendo relevante a ocorrência de fraturas patológicas na espécie. O principal foco de fratura mandibular em càes corresponde à região molar, principalmente próximo ao dente $1^{\circ}$ molar; na região rostral o principal foco envolve a regiào do dente canino.

Champion, T. ${ }^{4}$; Sincero, P.C. ${ }^{2}$; Locatelli-Dittrich, R.'; Franco, M.B. ${ }^{2}$; Sprea, G. ${ }^{3}$; Baudi, D.L.K. ${ }^{3}$; Silva, G.B. ${ }^{4}$

\section{7 - Artrite séptica em cão. Relato de caso}

1- MV, DR., Professor do Departamento de Medicina Veterinária da Universidade Federal do Paraná, Curitiba-PR

2- MV, MS, Professor do Departamento de Medicina Veterinária da Universidade Federal do Paraná, Curitiba-PR

3- MV, Mestranda do programa de Pós-graduação da Universidade Federal do Paraná, Curitiba-PR

4- Médica Veterinária do Hospital Veterinário da Universidade Federal do Paraná, Curitiba-PR

A artrite séptica é uma artropatia inflamatória, resultante de contaminação por via hematógena ou através de inoculaçào direta de um microrganismo. Os agentes infecciosos mais implicados no cão são Staphilococcus spp., Streptococcus spp., Escherichia coli, e em gatos Pasteurella spp. Além de bactérias, micoplasma, riquétsias, fungos e vírus também podem causar artrite séptica. A doença acomete principalmente càes, machos e de grande porte. Os sinais clínicos incluem claudicaçào, articulaçòes dolorosas, quentes e com efusão articular além de sinais sistêmicos, como febre, letargia e anorexia. A análise macroscópica do líquido sinovial revela evidências de doença articular, seja pela coloraçào, volume, coagulação ou viscosidade do líquido. $\mathrm{O}$ líquido sinovial normal possui população mista, inferior a 3.000 células $/ \mathrm{ml}$, com predominância de células mononucleares e os neutrófilos constituem menos de $12 \%$ do total. Em líquido sinovial de animais com artrite séptica, os neutrófilos representam maioria (acima de 90\%), podendo-se apresentar degranulados, tóxicos ou degenerados, havendo ainda elevação do nível de proteinas para valores acima de $2,5 \mathrm{~g} / \mathrm{dl}$. Animais com artrite imunomediada, por sua vez, podem ou não apresentar neutrofilia no líquido sinovial e neste caso, os neutrófilos possuem aparência normal. $\mathrm{O}$ aumento de células nucleadas mononucleares ocorre em várias doenças articulares crônicas e em articulações que tenham sofrido traumas ou alterações degenerativas. O objetivo deste trabalho é relatar a utilização da artrocentese e análise do liquido sinovial como diagnóstico diferencial de algumas artropatias, enfatizando que a cultura do líquido sinovial negativa nào descarta a artrite séptica como diagnóstico. O presente trabalho descreve um cào da raça Chow Chow, atendido no HV-UFPR que apresentava hiporexia e claudicação com o membro pélvico esquerdo há 10 dias. $\mathrm{O}$ animal já havia sido medicado com Carprofeno, porém além de não apresentar remissão dos sinais, ocorreu envolvimento de outras articulaçôes. Ao exame físico foram observadas febre, crepitação e sensibilidade dolorosa à palpação das articulações carporadial, fêmuro-tibio-patelar e coxo-femoral esquerdas. O hemograma revelou leucocitose 
por neutrofilia com desvio à esquerda. Ao exame radiográfico não se constataram alterações ósseas visiveis, apenas alterações em tecidos moles. A análise do líquido sinovial, obtido através de artrocentese da articulação fêmuro-tíbio-patelar esquerda, demonstrou líquido de aspecto turvo, coloraçào amarelada, proteínas elevadas $(6,8 \mathrm{~g} / \mathrm{dl})$, aumento na contagem total de células nucleadas $(12.700 / \mu \mathrm{l})$, com predominância de neutrófilos $(91 \%)$, e presença de neutrófilos degenerados. A cultura do líquido sinovial revelou ausência de crescimento bacteriano. $\mathrm{O}$ tratamento foi baseado em antibioticoterapia com Cefalexina e Carprofeno, como analgésico e anti-inflamatório. $\mathrm{O}$ animal foi reavaliado periodicamente e, após 30 dias de terapia, houve remissão total dos sinais clinicos. Os sinais clínicos, aliados aos resultados de exames laboratoriais, sobretudo a análise do liquido sinovial, indicando aumento na contagem total de células, com predominância de neutrófilos, presença de neutrófilos degenerados e elevaçào de proteínas permitiu definir o diagnóstico de artrite séptica. A artrocentese é um procedimento de baixo custo, requer equipamentos mínimos, envolvendo poucos riscos ao paciente, sendo a análise do líquido sinovial um método extremamente efetivo para diferenciação e diagnóstico de algumas artropatias.

Ibanez, J.F.'; Silva, T.S. ${ }^{2}$; Pontes, D.R. ${ }^{3}$

\section{8 - Uso do decanoato de nandrolona (Deca- durabolin ${ }^{\circledast}$ ) como estimulante da proliferação óssea em cães com consolidação retardada}

\author{
1 - Professor das disciplinas de Patologia e Clínica Cirúrgica e Anestesiologia da Faculdade de Medicina \\ Veterinária da Universidade das Faculdades Metropolitanas Unidas, São Paulo-SP \\ 2 - Médica Veterinária contratada do Serviço de Cirurgia de Pequenos Animais do Hospital Veterinário da \\ Faculdade de Medicina Veterinária da Universidade das Faculdades Metropolitanas Unidas, \\ São Paulo-SP \\ 3 - Médica Veterinária contratada do Serviço de Diagnóstico por Imagem do Hospital Veterinário da
} Faculdade de Medicina Veterinária da Universidade das Faculdades Metropolitanas Unidas, São Paulo-SP

Os esteróides anabolizantes são derivados sintéticos da testosterona, e foram idealizados com o intuito de separar os efeitos anabolizantes dos masculinizantes produzidos pela testosterona. O decanoato de nandrolona é um anabolizante esteroidal sintético com longo tempo de açào. Sua particular estrutura de cadeia, quando comparada a outros esteróides de cadeia tradicional, o torna um agente de baixa toxicidade hepática e com menores efeitos sobre o metabolismo lipídico. A utilização de anabolizantes esteroidais na osteoindução se deve a vários achados correlacionando a densidade óssea e níveis séricos de andrógenos em mulheres pré e pós-menopausa. Há relatos de diminuição de testosterona sérica em mulheres portadoras de osteoporose com fraturas vertebrais por compressão e fraturas de quadril. Nos homens, a massa de osso cortical é superior à das mulheres e permanece assim ao longo da vida. Há também evidencias de que a massa óssea está diretamente correlacionada com a massa muscular, maior nos indivíduos do sexo masculino e incrementada pelos anabolizantes esteroidais. Nos últimos anos as pesquisas centraram-se no fato de que osteoblastos humanos possuem receptores específicos para andrógenos. As células ósseas possuem RNAm (RNA mensageiro) para receptores androgênicos, indicando que os andrógenos possuem importante papel regulatório de suas funções. Outros estudos indicam que os andrógenos e anabolizantes esteroidais estimulam a proliferação e diferenciação osteoblástica, diminuem a atividade osteoclástica e incrementam a produção de $\mathrm{TGFb}$ (Fator transformados de crescimento b). Estudos demonstraram a atividade do decanoato de nandrolona diminuindo a reabsorção óssea em ratas ovariectomizadas. A intenção do presente estudo foi então, com base nos achados da literatura, investigar se o decanoato de nandrolona pode interferir nos casos de fraturas em que a consolidação óssea apresenta-se lenta ou tendendo à nào união. Algumas fraturas, como as de rádio e ulna distais são de consolidação lenta e não raro evoluem para não consolidação. $\mathrm{Da}$ mesma forma, outros fatores mecânicos e biológicos, como por exemplo, o envoltório muscular do foco de fratura 